\title{
A Mão Invisível de Júpiter e o Método Newtoniano de Smith ${ }^{\star}$
}

\author{
- Hugo E. A. da Gama Cerqueira*
}

\section{RESUMO}

Este ensaio discute o modo como Adam Smith compreendia a filosofia e a ciência, as motivações que orientam nossos esforços de conhecer a natureza e a sociedade e o método que deve orientar estas investigações e a exposição de seus resultados. Simultaneamente, o texto aponta os equívocos das interpretações que viram em sua obra uma expressão do mecanicismo e de uma espécie de "positivismo" avant la lettre.

\section{PalavRAS-CHAVE}

Adam Smith, retórica, metodologia, newtonianismo, economia política

\section{ABSTRACT}

This paper examines Adam Smith's understanding of the philosophy and science, the motivations that lead us to investigate nature and society, and the proper methods of investigation and exposition. The paper also criticizes those authors that interpret Smith's work as an example of the mechanical approach or as a kind of positivism avant la lettre.

\section{KEY WORDS}

Adam Smith, rhetoric, methodology, Newtonianism, political economy

JEL CLASSIFICATION

B30, B40

+ Trabalho realizado com o apoio do Conselho Nacional de Desenvolvimento Científico e Tecnológico (CNPq). As referências aos textos de Smith seguem a notação consagrada pela Edição Glasgow de sua obra.

* Professor do Cedeplar, Universidade Federal de Minas Gerais. Endereço para contato: Rua Curitiba, 832, $9^{\circ}$ andar, Belo Horizonte, MG, CEP 30170-120. E-mail: hugo@cedeplar.ufmg.br.

(Recebido em outubro de 2005. Aceito para publicação em fevereiro de 2006). 
Entre os aspectos que caracterizam os esforços atuais de reinterpretação do pensamento de Adam Smith merece ser destacada a tentativa de apreender compreensivamente as diferentes partes de sua obra, de tratar seus textos como partes de um todo integrado. A existência de uma estreita conexão entre os argumentos da Teoria dos sentimentos morais e da Riqueza das naçôes tem sido reconhecida pela maioria dos novos intérpretes, o que colocou em novas bases uma velha discussão, travada desde o século XIX, o assim chamado Das Adam Smith problem. (Cerqueira, 2005).

Se esta reorientação decorreu de razões e estímulos variados, é relevante notar que os novos intérpretes puderam se beneficiar da descoberta de textos inéditos de Smith, que eram desconhecidos de seus leitores do passado. Esta vantagem foi ampliada, a partir dos anos 1980, pelo lançamento de uma edição crítica reunindo todos os seus escritos conhecidos, a Edição Glasgow. Voltando os olhos para este conjunto mais abrangente de textos - cartas, manuscritos, notas de aula, além, naturalmente, dos dois livros que Smith publicou em vida - e considerando-os a partir de um ponto de vista que valoriza sua vinculação aos problemas e concepções próprios à filosofia moral do Iluminismo escocês, é possível colocar em questão o papel convencionalmente atribuído por economistas e historiadores à obra de Smith. Muito mais do que um continuador crítico da reflexão iniciada pelos mercantilistas e fisiocratas, seu sentido só se deixa apreender de modo integral se retivermos em mente os desafios e as motivaçóes que moldaram a trajetória do Esclarecimento na Escócia e ensejaram que seus expoentes formulassem uma compreensão peculiar dos problemas econômicos e sociais. (Cerqueira, 2006).

O esforço dos moralistas escoceses para formular um novo tipo de teoria social inspirou-se, em larga medida, na ambição de transpor para a filosofia moral o bem-sucedido método proposto por Newton em sua filosofia da natureza. É tendo em vista este movimento de apropriação coletiva do método newtoniano que buscaremos explicitar neste ensaio o modo como Smith compreende a filosofia e a ciência: sua natureza, os motivos que orientam nossos esforços de conhecer, e os métodos que devem ser seguidos, seja na investigação, seja na exposição dos resultados alcançados. Ao mesmo tempo procuraremos desfazer os equívocos acumulados ao longo do tempo por interpretações que afirmaram na obra de Smith uma adesão ao mecanicismo e a um "positivismo" avant la lettre, equívocos que sustentaram leituras enganadoras de sua economia política.

\section{RETÓRICA E DISCURSO CIENTÍFICO}

Nos últimos anos de sua vida, a saúde de Adam Smith foi se deteriorando gradualmente. Na verdade, ele nunca desfrutou de uma constituição física vigorosa: referên- 
cias a dores e queixas de enfermidades são relativamente comuns em sua correspondência. Há indícios de que fosse hipocondríaco e ele próprio reconheceu certa vez que tinha a mente melancólica e propensa a maus presságios (Corr. 286). Numa carta a um velho amigo, escrita em março de 1787, ele lamentava que seu estado de saúde estivesse "bem pior que o usual." (Corr. 266). Smith tinha, então, 63 anos, e como ele mesmo lembrou, vivia seu "grande climatério" (grand climacteric). ${ }^{1}$ Naquele inverno, uma obstrução crônica dos intestinos voltaria a lhe importunar e seus amigos anteviram a possibilidade de sua morte. (Rae, 1965, p. 402). Mas ele se recuperaria desta crise e sua vida só chegaria ao fim três anos mais tarde, em julho de 1790. Aparentemente, sua morte resultou de uma evolução lenta e dolorosa da mesma doença que, de acordo com seus companheiros, ele soube suportar com a resignação e o autodomínio próprios de um estóico. (Stewart, 1982, p. 327).

A partir do inverno de 1786-87, período em que notou uma piora em seu estado de saúde, Smith manifestou seguidas vezes sua preocupação com o destino que deveria ser dado aos escritos que mantivera inéditos. De acordo com o depoimento de um de seus amigos mais íntimos, James Hutton, ${ }^{2}$ naquele período ele "reuniu seus amigos $e$ confiou-lhes a posse de seus manuscritos, a fim de que, quando morresse, destruissem todos os volumes de suas conferências, e fizessem o que bem entendessem com o restante." (Stewart, 1982, p. 327). Mais tarde, em fevereiro de 1790, debilitado pela doença, e prevendo, talvez, que sua morte pudesse ocorrer em breve, ele fez um testamento em que designava David Douglas ${ }^{3}$ como o seu principal herdeiro, legando a ele tudo o que possuía, inclusive sua valiosa biblioteca, e instruindo-o a dar um destino aos manuscritos de acordo com os conselhos que seriam fornecidos por James Hutton e por Joseph Black, ${ }^{4}$ a quem Smith dera instruçôes "verbais ou escritas" sobre o assunto. De acordo com o testemunho de um terceiro amigo, ele lamentou, por volta da mesma época, ter feito "tão pouco" e declarou que pretendera "fazer mais, pois há muitas informações em meus papéis que poderia ter utilizado. Mas agora tudo isso está fora de questão." (Stewart, 1982 , p. 328). Sentindo que a morte se avizinhava, voltou a insistir com os amigos a

1 De acordo com uma antiga crença invocada por Smith, o sexagésimo terceiro ano de vida corresponderia ao período em que ocorreriam as últimas e mais graves crises na existência de um homem.

2 Geólogo, químico e naturalista escocês, James Hutton (1726-1797) foi o autor de Teoria da terra [Theory of the earth], livro que lançou as bases da teoria moderna sobre a formação da crosta terrestre. Foi o criador do uniformitarianismo (uniformitarianism), doutrina que afirma que o passado geológico da Terra deve ser compreendido com base em fatores causais análogos aos que existem no presente, levando à conclusão de que a idade do planeta é muito superior à que se supunha até então.

3 David Douglas (1769-1819), que se tornaria lord Reston, era o filho mais novo de um dos primos de Smith, Robert Douglas de Strathenry. Em 1778, quando Douglas contava apenas 9 anos de idade, Smith o recebeu em sua casa e se afeiçoou ao menino, cuidando de sua educação até encaminhá-lo, mais tarde, à Universidade de Glasgow para ali completar seus estudos.

4 Filho de um comerciante de vinhos de ascendência escocesa, Joseph Black (1728-1799) nasceu em Bordeaux, tranferindo-se para a Escócia aos 16 anos a fim de estudar na Universidade de Glasgow. Ali cursou medicina e foi assistente de William Cullen (1710-1790), que foi o pioneiro no ensino de química naquela universidade. Tornou-se um químico respeitado por seus estudos sobre o calor específico e latente e pela descoberta do dióxido de carbono (fixed air). 
respeito do destino que desejava dar aos manuscritos, sendo por eles apaziguado com a promessa de cumprirem sua vontade. Nos meses seguintes, a ansiedade de Smith em relação a este assunto voltou a crescer: num domingo, 11 de julho, ele voltou a implorar a um de seus amigos que destruísse imediatamente os volumes que não desejava que fossem conhecidos do mundo. No mesmo dia, eles foram lançados ao fogo, sem que nem mesmo os mais íntimos soubessem de seu exato conteúdo. De acordo com Hutton, Smith teria ficado tão aliviado com esta providência que se sentiu disposto para receber naquela noite um grande número de seus amigos, como fazia habitualmente aos domingos. Porém, seu estado de saúde já havia se complicado bastante, e ele foi obrigado a se retirar para seu quarto antes mesmo da ceia. Ao despedir-se dos seus convidados, disse que teriam que adiar aquele encontro para "um outro lugar". Seu fim chegou alguns dias mais tarde, no sábado seguinte a esta última reunião. Smith estava acompanhado por Black e Hutton, que além de amigos eram também os médicos que o assistiam, quando, por volta da meia-noite, a morte o colheu.

Desde aquele dia seriam muitos a lamentar o destino dado aos escritos que Smith insistira em ver destruídos. Pouco tempo depois de seu enterro, outro amigo, Robert Beatson, escreveu que "o mundo tem razão para lamentar que alguns dias antes de morrer ele tenha mandado queimar nove ou dez volumes de seus manuscritos - ele não os considerava suficientemente terminados para serem dados ao mundo." (Citado em Ross, 1995, p. 406). O gesto que foi qualificado por Dugald Stewart (1982, p. 327), seu discípulo e primeiro biógrafo, como um "irreparável prejuízo às letras". O conteúdo destes papéis tem sido objeto de intensa especulação. Para Stewart (1982, p. 327), parte deles consistiria de textos sobre retórica que Smith leu em Edimburgo em 1748 e o restante seria composto pelas lições sobre religião natural e jurisprudência que ele pronunciou em Glasgow. A descoberta de uma carta dirigida por Smith ao Duque de La Rochefoucauld, e datada de novembro de 1785, mas só publicada em 1895, forneceu outras pistas sobre o possível conteúdo dos manuscritos incinerados. Nela, Smith afirma ter reunido e posto em ordem boa parte do material necessário à composição de duas obras que tinha em vista: "a primeira é uma espécie de história filosófica de todos os diferentes ramos da literatura, da filosofia, poesia e eloqüiencia; a outra é uma espécie de teoria e história do direito e do governo." Na mesma carta, Smith admite que considerava muito incerta a efetiva realização destes dois projetos, pois sentia que aquela indolência própria dos idosos já se apossava rapidamente dele. (Corr. 248).

O fato é que sua decisão de dar cabo daqueles papéis não deve ser tomada como reflexo de um impulso repentino ou impensado. Há boas razões para considerar que esta tenha sido uma deliberação tomada muito tempo antes de sua morte e preservada ao

5 Henry Mackenzie, outro participante daquela reunião, reportaria a frase de despedida de Smith de uma maneira algo distinta. Ele teria dito: "Eu aprecio sua companhia, cavalheiros, mas creio que devo deixar-lhes para ir para um outro mundo." (Citado em Rae, 1965, p. 435). 
longo de anos. Ainda em 1773, quando teve que se ausentar da Escócia por um período prolongado, Smith escreveu a Hume designando-o seu testamenteiro literário e deixando instruções sobre o que fazer dos textos que se encontravam em sua casa. De acordo com ele, deveriam ser destruídos "sem qualquer exame" todos os papéis soltos, bem como dezoito pastas de manuscritos que havia em seu quarto, preservando-se da destruição apenas os manuscritos da Riqueza das nações, que levaria consigo em sua viagem, e "uma pequena obra (...) numa pasta fina na minha escrivaninha em meu quarto.” (Corr. 137).

Tamanha preocupação com o destino de seus escritos desperta, naturalmente, uma certa curiosidade sobre as razões que Smith teria para temer sua divulgação. Duas hipóteses plausíveis foram levantadas por Stewart (1982). A primeira seria uma excessiva preocupação de Smith com sua reputação póstuma. De fato, este tipo de zelo já se manifestara anteriormente, quando da morte de Hume, que, ao contrário do que Smith imaginara, ocorreria bem antes da sua. Hume o havia designado para executar seu testamento literário - invertendo-se os papéis, deste modo, em relação ao que ocorrera da primeira vez. Isto significava que caberia a Smith a tarefa de editar postumamente a Minha própria vida [My own life] e os Diálogos sobre religião natural [Dialogues concerning natural religion]. 6 No curso dos trabalhos de publicação da autobiografia de Hume, o editor propôs que também fossem publicadas anexas ao texto algumas das cartas escritas por ele. Como bom amigo e fiel testamenteiro, Smith reagiu prontamente, e de modo enfático, contra esta sugestão. Alegou que esta não era a vontade do autor, que sempre se opusera à publicação de sua correspondência. Acrescentou que, mesmo que a publicação se restringisse a uma seleção cuidadosa da correspondência, de modo a fazer justiça à reputação e à honra de Hume, uma boa recepção pelo público acabaria servindo de estímulo a que editores imprudentes se lançassem à cata de outras cartas, compondo com elas novos volumes e, deste modo, "seriam publicadas muitas coisas que não eram próprias para vir à luz, para a grande mortificação de todos aqueles que desejam bem a sua memória." (Corr. 181). ${ }^{7}$ Tendo sido esta a atitude de Smith para com a reputação póstuma de seu amigo, é razoável inferir que o mesmo tipo de preocupação o movia quando decidiu queimar seus manuscritos.

Por outro lado, uma segunda consideração poderia estar por trás dessa decisão, uma motivação de tipo "mais elevado": a hipótese de que, tendo consciência da autoridade que sua opinião comandava, Smith estivesse preocupado com a possibilidade de que a divulgação daqueles trabalhos acabasse sancionando argumentos que atrasariam o

6 Smith relutou tanto em aceitar o encargo de editar os Diálogos, que Hume terminou transferindo a responsabilidade para seu sobrinho, David Hume, o jovem. (Ross, 1995, p. 288-300).

7 Na mesma carta Smith comenta que nada fora mais desfavorável à apreciação do valor das obras de Swift do que a publicação indiscriminada de sua correspondência. Este juízo parece ter sido compartilhado por outros contemporâneos: o mesmo Robert Beatson, que lamentara a queima dos manuscritos de Smith (cf. p. 670), sugeriu que essa decisão poderia ter sido influenciada pelo tratamento que George Faulkner, o editor de Swift, dera às edições póstumas de sua obra. (Citado em Ross, 1995, p. 406). 
"progresso da verdade", ao invés de promovê-lo. Deste modo, ele teria se contentado com a divulgação apenas daqueles argumentos que considerava mais interessantes para a humanidade. (Stewart, 1982, p. 327). As duas explicaçôes, zelo excessivo por sua reputação e preocupação com o efeito de seus textos, são compatíveis com o que sabemos sobre o lento processo de composição seguido por Smith: as cuidadosas revisões que fez para cada uma de suas obras, quão difícil e trabalhoso era para ele o processo físico de escrever e o fato de que nada disso o impediu de se esforçar por "construir e demolir" o próprio texto até conseguir atingir a expressão apropriada que tanto buscava. ${ }^{8}$

De qualquer modo, o que importa frisar para nosso argumento é que tanto a preocupação de Smith com seus textos inacabados quanto a decisão meditada sobre o destino que deveriam receber após sua morte conferem aos manuscritos que foram poupados da destruição uma autoridade peculiar. Em relação a eles, não há razão para duvidar de que representem fielmente as intenções do seu autor e de que estejam de pleno acordo com seu pensamento. ${ }^{9}$ Nos anos que se seguiram ao falecimento de Smith, seus amigos Hutton e Black empenharam-se em ver aqueles textos publicados. Eles foram reunidos num volume de Ensaios sobre temas filosóficos [Essays on philosophical subjects], lançado em Londres, em 1795, e que também incluía a biografia de Smith escrita por Dugald Stewart. ${ }^{10} \mathrm{O}$ livro abrigou um conjunto heterogêneo de trabalhos inéditos, com graus de acabamento diferenciados, dos quais os mais importantes são os três ensaios sobre "os princípios que orientam e dirigem as investigações filosóficas", a saber: a História da astronomia [The principles which lead and direct philosophical enquiries; illustrated by the history of astronomy], a História da física antiga [The principles ...; illustrated by the history of the ancient physics] e a História da lógica e metafisica antigas [The principles ...; illustrated by the history of the ancient logics and metaphysics]. Além deles, o volume incluía, ainda, o ensaio sobre os Sentidos externos [Of the external senses] e um outro sobre as Artes imitativas [Of the nature of that imitation which takes place in what are called the imitative arts]. ${ }^{11}$ À exceção deste último, cuja redação data de 1777 , presume-se que a composição dos demais textos remonte ao período da juventude de Smith.

Não resta dúvida de que, como disse Schumpeter (1994, p. 182), a "pérola da coleçãa" seja o primeiro dos três ensaios sobre os "princípios que orientam e dirigem as investiga-

8 Há mais de uma referência ao "construir e destruir" que caracterizou o processo de redação da Riqueza das nações e que fez com que os amigos de Smith temessem não ver aquele trabalho concluído. (Ross, 1995, p. 244-245).

9 Neste sentido, parecem impróprias as restrições formuladas por Wightman (1982, p. 26-27) à publicação de alguns dos ensaios inacabados.

10 Ủma outra edição apareceu no mesmo ano em Dublin e foi seguida por outra edição impressa na Basiléia, em 1799, e por uma tradução francesa publicada em 1797.

11 Nas ediçóes posteriores dos Ensaios outros trabalhos seriam incorporados ao conjunto original de textos, como as contribuições escritas por Smith para a Edinburgh Review e uma apresentação do livro de poemas de William Hamilton. 
çôes filosóficas. "12 Trata-se do texto mais longo do livro e que ficou conhecido como o ensaio sobre a História da astronomia, pois procura ilustrar aqueles princípios fazendo referências à história desta disciplina. É este o trabalho que Smith mencionou como "uma pequena obra (...) numa pasta fina" que se encontrava em sua escrivaninha quando escreveu a Hume em 1773 para recomendar que o restante de seus papéis fosse destruído se porventura morresse. Ele descreveu o texto como "um fragmento de uma grande obra que contém uma história dos Sistemas Astronômicos que estiveram sucessivamente em uso até a época de Des Cartes." Smith deixou a cargo de Hume a decisão de publicar aquele "fragmento de uma obra planejada na juventude", acrescentando com a costumeira e severa autocrítica que "começara a suspeitar que há mais refinamento que solidez em algumas de suas partes." (Corr. 137).

A expressão "fragmento de uma obra planejada na juventude", usada para qualificar o ensaio, fornece uma primeira indicação do período em que foi composto. Para alguns estudiosos, sua redação pode ter sido iniciada ainda antes de 1746, durante o período em que Smith foi bolsista em Oxford. (Wightman, 1982, p. 7). Um conjunto de outras evidências faz crer que a redação (ou boa parte dela) date do período entre 1748 e 1751, durante o qual Smith proferiu palestras públicas sobre retórica e, posteriormente, sobre história da filosofia e do direito em Edimburgo. (Ross, 1995, p. 98). O convite para realizar estas preleções partiu de Henry Home, o futuro Lord Kames, que assumiu em 1748 o cargo de vice-presidente da Philosophical Society, entidade que foi a provável patrocinadora daquelas lições. De fato, a idéia de promover palestras sobre retórica encaixava-se nas preocupações de Home, que considerava o bom gosto como um sinal distintivo da coesão social. Por outro lado, também coadunava com o interesse da Philosophical Society de Edimburgo que, tomando por inspiração o modelo provido pela Royal Society de Londres, desejava estimular a adoção de uma nova forma de expressão - natural, clara e simples, desprovida de digressões e de exageros de estilo - tal como a nova retórica ensinada por Smith. ${ }^{13}$ Além disso, Smith era capaz de se expressar com fluência naquele padrão da língua inglesa empregado entre os círculos do governo e da nobreza da Inglaterra, o que era invejado pelos escoceses. Não sabemos em que local foram dadas as palestras, nem mesmo seu conteúdo exato, mas temos informações sobre alguns dos ouvintes que compunham sua platéia, formada

12 Schumpeter acrescenta na mesma passagem que não se pode ter uma idéia correta da estatura intelectual de Smith sem conhecer estes ensaios, mas não parece extrair deles qualquer conseqüência para a interpretação de sua obra econômica. (1994, p. 182).

13 Entre os fatores que influenciaram esta reorientação de estilo estariam, de um lado, a autoridade da ciência newtoniana expressa institucionalmente por meio da Royal Society e, de outro, a influência da filosofia de Locke, em particular, do seu Ensaio [Essay concerning human understanding]. (Brown, 1994, p. 11). Que este estilo conciso e simples era defendido por Smith em suas preleções sobre retórica é algo que fica claro em diferentes passagens das liçôes 2, 6, 7 e 11. Numa delas, ele afirma: "Quando o sentimento do orador é expresso de uma maneira simples, clara, direta e inteligente, e a paixão ou inclinação de que ele é possuidor e pretende, através da simpatia, comunicar ao seu ouvinte é representada de maneira direta e inteligente, então e apenas então a expressão tem toda a força e a beleza que a linguagem pode dar a ela." (LRBL i.v.56). 
na maioria por estudantes de direito e teologia. Também é possível formar uma idéia sobre os temas discutidos a partir dos relatos das lições sobre retórica que ele proferiu depois de se transferir para Glasgow, em 1751, e que parecem retomar sem maiores alterações o teor das preleções feitas em Edimburgo. (Ross, 1995, p. 84-87). ${ }^{14}$

Não é este, entretanto, o lugar para tecer considerações mais detalhadas sobre a natureza específica da concepção de retórica proposta por Smith. ${ }^{15}$ De suas lições interessa-nos, por ora, reter o comentário que faz sobre um gênero específico de prosa que ele denomina de didático ou científico e cujas regras afirma serem "bastante óbvias”. (LRBL ii.97).

Smith dedicava mais da metade de seu curso (as últimas dezenove aulas) à apresentação dos quatro gêneros literários que compõem sua retórica: o histórico, o poético, o científico (ou didático) e o retórico (ou oratório). O primeiro gênero corresponde ao discurso narrativo, cujo objetivo é descrever ou relatar fatos. Quanto ao segundo gênero, poético, Smith argumenta que ele segue, em grande medida, as regras associadas às narrativas históricas, mas que seu objetivo é diverso, pois visa a divertir ou entreter a humanidade. ${ }^{16}$ Por outro lado, quando o discurso não tem por finalidade narrar fatos, mas sim provar alguma proposição, ele pode assumir duas formas distintas, a saber: o discurso didático e o discurso retórico. Este último, "esforça-se por nos persuadir através de todos os meios e, para alcançar este propósito, ele exagera todos os argumentos de um lado e diminui ou encobre aqueles que poderiam ser apresentados do lado contrário ao qual ele está destinado a nos fazer favorecer." (LRBL i.149-150). O discurso didático, por sua vez, "pretende colocar diante de nós os argumentos de ambos os lados da questão em seu ângulo verdadeiro, dando a cada um o seu grau apropriado de ascendência e tem em vista persuadir não mais do que os próprios argumentos afiguram-se convincentes." (LRBL i.149). Deste modo, persuadir é a intenção principal do discurso retórico e a instrução joga aí um papel subserviente em relação ao esforço de persuasão, ao passo que o discurso didático tem por finalidade primordial a instrução e apenas secundariamente a persuasão.

Nos cursos sobre retórica ministrados em Glasgow - particularmente naquele que lecionou em 1762-63 - Smith reservou a vigésima quarta preleção para uma análise detida deste último tipo de discurso. Ali ele reafirma que no discurso didático "o intuito do escritor é estabelecer uma proposição e prová-la através dos diferentes argumentos

14 O conteúdo das lições pode ser conhecido por meio de depoimentos de contemporâneos que chegaram até nós e, sobretudo, pelas anotações que estudantes fizeram das aulas ministradas por Smith em 1762 63. Estas notas foram descobertas em 1958 e publicadas pela primeira vez em 1963, com o título de Lectures on rhetoric and belles lettres $(L R B L)$.

15 Ver, a este propósito, Howell (1975) e Vivenza (2001, p. 159-184).

16 Howell $(1975$, p. $26 ; 29)$ nota que no início do curso Smith não inclui a composição poética entre as formas de discurso (LRBL i.149). Contudo, mais adiante, na aula de número 21 , ela surge associada às narrativas históricas. 
que conduzem àquela conclusão.” (LRBL ii.125). Quando o objetivo é provar apenas uma proposição, sugere que esta seja firmada logo de início e, em seguida, que sejam expostos os argumentos que se destinam a prová-la. Smith insiste que a proposição a ser provada deve ser exposta desde o início, pois isto contribui para amplificar a influência e o efeito, sobre a mente do leitor, dos argumentos aduzidos posteriormente em sua prova. Porém, por vezes será necessário provar uma série de proposições subordinadas para que se possa demonstrar a proposição principal. Neste caso, ele afirma, será necessário apresentar a proposição principal, mostrar como sua prova depende de outras proposições e, tendo provado cada uma delas, recapitular o seu conjunto. Nesta passagem, Smith demora-se em mostrar que o número de proposições subordinadas não deve exceder a cinco - e, de preferência, estar limitado a três -, de modo a facilitar sua compreensão pela mente. ${ }^{17}$ Se o seu número for maior, as proposições diretamente subordinadas à principal não devem ultrapassar a 3 ou 5 , sendo as demais agrupadas sob cada uma delas em grupos de 3 ou 5 proposições relacionadas, de maneira a permitir que a mente tenha uma apreensão clara do plano do texto. Deste modo, conclui, é possível evitar aquela impressão que ocorre a quem lê as obras de Aristóteles, nas quais o número de divisões e subdivisões é exagerado e termina por provocar confusão no leitor. (LRBL ii.127-130).

Segundo Smith, estas divisões são ainda mais úteis quando o discurso visa não apenas provar uma proposição mas "expor um sistema de alguma ciência, por exemplo, a filosofia natural", que é a segunda função do discurso didático ou científico. Neste tipo de discurso, a exposição de um sistema pode ser feita de duas maneiras distintas:

"Ou bem formulamos primeiramente um ou alguns poucos principios pelos quais explicamos as várias normas ou fenômenos conectando-os um ao outro em uma seqüência natural, ou então começamos por dizer que vamos explicar tais e tais coisas e para cada uma delas propomos um principio diferente ou igual aos que foram propostos anteriormente." (LRBL ii.132).

Para ilustrar esta segunda maneira de redigir um discurso didático, Smith refere-se ao método adotado por Virgílio para compor os quatro livros das Geórgicas: sendo seu objetivo expor um sistema de cultivo agrícola (busbandry), ele trata no primeiro livro do cultivo de cereais, em seguida das árvores, depois do gado e, finalmente, da apicultura. De acordo com Smith, este é também o método empregado por Aristóteles, quando examina os diferentes ramos da filosofia na ordem em que vão surgindo para nós e associa cada fenômeno a um princípio que, em geral, é distinto dos apresenta-

17 "Três ou algum número próximo deste é um número bastante adequado (...). Três é dentre todos os outros números o mais facilmente compreendido; nós percebemos imediatamente um ponto mediano e outro ponto de cada lado." (LRBL ii.127). 
dos anteriormente. Mas o método que o próprio Smith considera mais adequado à composição dos discursos científicos, aquele que ele considera "o mais filosófico" (the most philosophicall one), é diverso deste adotado por Virgílio e Aristóteles. Trata-se, ao contrário, daquela outra maneira de proceder mencionada acima, ou, ainda, do método adotado por Isaac Newton:

"podemos estabelecer no inicio certos princípios conbecidos ou provados a partir dos quais explicamos os vários fenômenos, conectando-os todos juntos pela mesma cadeia. Esse último [método], que podemos chamar de método newtoniano, é sem dívida o mais filosófico e em cada ciência, quer se trate da moral ou da filosofia natural etc., é imensamente mais engenhoso e, por esse motivo, mais atraente que o outro. Dá-nos satisfação ver os fenômenos que considerávamos os mais inexplicáveis, deduzidos todos de algum principio (normalmente um principio bem conbecido) $e$ unidos todos em uma cadeia; uma satisfação muito superior à que sentimos em relação ao método desconexo, onde tudo é explicado por si só sem qualquer referência aos demais." (LRBL ii.133-134).

Há mais coisas a destacar nesta passagem do que a evidente admiração de Smith por Newton, aspecto que ainda examinaremos mais adiante. Por ora, é preciso frisar, em primeiro lugar, que Smith recomenda o método newtoniano tanto à ciência (ou filosofia) natural quanto à filosofia moral, o que sugere que é esta mesma concepção de método que prevalecerá em sua obra. (Vivenza, 2001, p. 170). Em segundo lugar, há que notar na mesma passagem o aparecimento daquela noção de conexão ou cadeia que, ligando os fenômenos aos princípios, conduz a um estado de satisfação que é interrompido sempre que se observa uma lacuna ou falha na seqüência dos fenômenos ou do argumento. ${ }^{18}$ Esta idéia de um encadeamento a partir do qual se constrói um sistema cuja beleza é capaz de apaziguar a mente e provocar um sentimento de prazer será retomada em outras passagens das diferentes obras de Smith. (Bryce, 1985, p. 34-37).

$\mathrm{Na}$ Riqueza das nações, por exemplo, ele se refere à "beleza de um arranjo sistemático de observaçôes diversas, vinculadas entre si por alguns poucos princípios comuns." (WN V.i.f.25), um arranjo que teria surgido inicialmente, ainda que de maneira tosca, nas tentativas que pensadores da Antiguidade empreenderam para compor um sistema de filosofia natural. A estas tentativas, Smith contrapôs os esforços anteriores de compilar desordenadamente máximas de moralidade, como as fábulas de Esopo ou os provérbios de Salomão, que não se preocuparam em "dispô-las em ordem clara ou metódica, e muito menos coordená-las de acordo com um ou mais principios gerais, dos quais se pudesse deduzi-las todas." (WN V.i.f.25).

18 Tratando das narrativas históricas em outra preleção, Smith nota que "nós não devemos nunca deixar quaisquer falhas ou lacuna no fio da narração (...). A mera idéia de uma lacuna nos torna inquietos." (LRBL ii.36). 
No ensaio sobre as Artes imitativas, Smith retoma o tema, sugerindo que a harmonia dos diferentes sons e instrumentos num concerto bem composto de música instrumental é capaz de preencher por completo a mente, ocupando-a de modo a não deixar espaço para que qualquer outro objeto distraia nossa atenção. E complementa:

"Na contemplação desta imensa variedade de sons agradáveis e melodiosos, arranjados e compilados tanto em sua coincidência quanto em sua sucessão em um sistema tão completo e harmonioso, a mente, na verdade, desfruta não apenas um intenso prazer sensual, mas também um grande prazer intelectual, prazer que não é dessemelhante daquele que ela extrai da contemplação de um grande sistema em qualquer outra ciência." (Imitative Arts II.30).

Convém frisar que é este efeito prazeroso sobre a mente proporcionado pela observação de um sistema harmonioso que determina a superioridade do método newtoniano na organização dos discursos científicos. Para Smith, isso permitiria compreender como a filosofia cartesiana encontrou uma recepção tão favorável entre os homens letrados de sua época, a despeito de não conter, talvez, um só grão de verdade, pois, afirma, Descartes foi o primeiro a empregar o método dito newtoniano, e a superioridade deste é tão grande em relação ao método aristotélico que prevalecia até então, que fez com que os seus contemporâneos, além de tudo pouco conhecedores daqueles assuntos, recebessem seu sistema com avidez. (LRBL ii.133-134).

Mas tudo isso ficaria ainda mais claro no ensaio sobre a História da astronomia, em que a concepção de Smith sobre o método a ser adotado nas investigações filosóficas é amplamente discutida. É hora, então, de nos voltarmos para esse texto.

\section{UMA PSICOLOGLA DO CONHECIMENTO}

O ensaio é composto de quatro partes, das quais apenas a última trata propriamente da história da astronomia. Nela, Smith percorre os principais sistemas astronômicos (ou "da natureza") que foram sucessivamente adotados pelos homens letrados: o sistema das esferas concêntricas, cuja criação é atribuída aos pitagóricos e que teria sido aperfeiçoado por Aristóteles e Eudoxo (Astronomy IV.4); o sistema das esferas excêntricas e epiciclos, formulado por Apolônio de Perga e aprimorado por Hiparco e Ptolomeu (IV.8); e, finalmente, os sistemas modernos de Copérnico, Descartes e Newton (IV.71 ss.). Para o nosso propósito, entretanto, o interesse desta parte do ensaio é reduzido, limitando-se a proporcionar algumas ilustrações dos princípios estabelecidos nas três primeiras seções, isto é, dos "princípios que orientam e dirigem as investigações filosóficas”. 
Nas seções iniciais do ensaio, Smith desenvolve uma espécie de psicologia (ou antropologia) do conhecimento apoiada num esforço para elucidar a natureza específica de três diferentes sentimentos humanos: o assombro (wonder), a surpresa (surprise) e a admiração (admiration). Desde suas linhas iniciais, o objetivo do ensaio é definido como sendo o de "considerar particularmente a natureza e as causas de cada um destes sentimentos, cuja influência tem um alcance muito mais amplo do que estaríamos aptos a imaginar com base em um exame descuidado." (Astronomy 7). Para Smith, tal investigação se apresentaria como necessária, em primeiro lugar, porque estes sentimentos são freqüentemente confundidos em razão do fato de estarem associados entre si, o que requer um esforço preliminar de precisar o sentido que deve ser atribuído a cada um deles; em segundo lugar, porque só com base na sua compreensão é possível dar conta daquilo que move os homens em direção ao conhecimento.

Começando pelo primeiro ponto, Smith esclarece que pela palavra assombro nos referimos ao efeito provocado por aquilo que é novo e único, pelos objetos "extraordinários ou incomuns", tal como meteoros ou cometas ou coisas com as quais temos pouca ou nenhuma familiaridade. Quanto à surpresa, corresponde à impressão provocada sobre a mente ao nos depararmos com objetos aos quais estamos acostumados, mas que não esperávamos encontrar em determinada circunstância, como quando surge diante de nós uma pessoa bastante conhecida mas que não contávamos ver naquele momento ou lugar. Finalmente, a admiração corresponde ao sentimento provocado por algo que é grande ou belo, mesmo que este objeto já seja conhecido por nós e não haja nele nada além do que esperávamos ver. (Astronomy; I.5;1-4).

Em uma passagem que deixa transparecer claramente a influência de Hume, ${ }^{19}$ Smith observa que os efeitos destes sentimentos podem ser melhor apreendidos se levarmos em conta o papel que os hábitos e os costumes jogam na determinação do modo como somos afetados pelos objetos dos sentidos. De acordo com ele, o fato de nos acostumarmos a algum objeto, de estarmos habituados à sua presença repetida e freqüentemente diante de nós, termina "por dar forma e submeter a mente ou o órgão àquele humor e disposição habituais que os habilita a receber sua impressão sem passar por uma mudança violenta." (Astronomy I.10). Neste sentido, a presença de algum objeto que já era aguardado ou previsto provoca uma mudança menos considerável sobre o espírito do que o surgimento de algo inesperado, na medida em que, ao nos anteciparmos à sua presença, podemos nos preparar de antemão para ela. Qualquer que seja a emoção despertada por um objeto, a simples presença de sua idéia na mente por algum tempo basta para provocar aquela mesma emoção, ainda que de modo menos intenso; de tal modo que, quando o objeto surge efetivamente, "a emoção ou paixão que ele provoca passa-se gradualmente e com facilidade para o coração, sem violência, dor

19 Cf., sobretudo, a seção "sobre a conexão ou associação de idéias" do Tratado da natureza humana. (Hume, 1978, p. 10-13). 
ou dificuldade." (Astronomy I.1). O contrário disso ocorre quando o objeto aparece de modo inesperado, pois neste caso "a paixão é derramada de uma só vez no coração, que é arrastado, se a paixão é forte, às mais intensas e violentas emoções.” (Astronomy I.2). É nesta mudança abrupta e violenta sobre a mente que consiste, propriamente, a natureza da surpresa.

De modo análogo, Smith afirma que a mente extrai um prazer ao perceber semelhanças entre diferentes objetos, pois é deste modo que ela consegue organizar e ordenar as idéias, agrupando objetos distintos em classes e grupos segundo as características que apresentem em comum. Este sentimento é, entretanto, perturbado pelo surgimento de um objeto novo e singular, de algo que a memória não é capaz de reconhecer e que a imaginação não consegue relacionar a qualquer grupo ou espécie de coisas que conheçamos. Neste caso, a mente é arrancada de seu repouso e tranqüilidade, vagando de pensamento em pensamento enquanto permanece incapaz de livrar-se daquela incerteza quanto à natureza ou classe do objeto. Este movimento oscilante da imaginação e a tentativa frustrada da memória de encontrar alguma recordação do objeto constituem, em conjunto com a emoção que despertam, o sentimento que denominamos de assombro. (Astronomy II.4). A mente só pode restaurar o seu estado anterior após haver conectado o objeto a outros que se assemelhem estreitamente a ele, reunindo-os sob algum novo grupo ou classe de coisas, livrando-se assim daquele assombro, daquela incerteza e curiosidade de que foi tomada.

O sentimento de assombro pode também ocorrer quando, ao invés de um objeto incomum, a mente se depara com uma sucessão de objetos que comparecem numa ordem ou seqüência diversa daquela que lhes é usual. Nesta passagem, em que, mais uma vez, é possível perceber com nitidez a influência de Hume (1978, p. 187-218), Smith nos explica que quando dois objetos, por mais diferentes que sejam, se apresentam rotineiramente numa certa seqüência, tornam-se conectados na imaginação, de tal modo que a idéia de um objeto parece convocar e introduzir a idéia do outro. Esta associação de idéias torna-se tão mais estrita quanto mais vezes os objetos se apresentarem naquela seqüência e, deste modo, "o hábito da imaginação de passar da concepção de um [objeto] a outro torna-se cada vez mais fixado e confirmado." (Astronomy II.7). A partir de então, quando os objetos se apresentarem naquela mesma seqüência à qual a imaginação está acostumada, eles parecerão estar conectados entre si e o pensamento deslizará entre eles facilmente, “sem esforço ou interrupção”. Porém, afirma,

"... se esta conexão costumeira se interrompe, se um ou mais objetos aparecem numa ordem muito diversa daquela que a imaginação está acostumada e para a qual está preparada, ocorre o contrário disso tudo. Somos primeiramente surpreendidos pelo inesperado do novo aparecimento e quando essa emoção momentânea acaba, nós ainda nos perguntamos 
(wonder) como ela pôde ocorrer naquele lugar. A imaginação não sente mais a facilidade usual de passar do evento que ocorre antes para aquele outro que ocorre em seguida." (Astronomy II.8).

Em resumo, a mudança na ordem em que os objetos se apresentam provoca inicialmente a surpresa, que é seguida pelo assombro que decorre da súbita interrupção no curso da imaginação que, hesitando em passar de um a outro objeto, percebe a existência de uma espécie de lacuna ou intervalo entre eles. Retirada de seu repouso e lançada em um estado de desconforto e apreensão, a imaginação deve encontrar "algo que possa preencher esta brecha, algo que, como uma ponte, possa ao menos unir aqueles objetos aparentemente tão distantes, de modo a tornar suave, natural e fácil a passagem do pensamento por entre eles." (Astronomy II.8). Para tanto, ela só pode recorrer à suposição de que existe alguma cadeia intermediária de eventos, mesmo que tal cadeia nos seja invisível, eventos que sigam uma ordem similar àquela que a imaginação está acostumada e que sejam capazes de unir os objetos separados por aquele intervalo.

Para exemplificar seu argumento, Smith refere-se a uma peça de metal disposta sobre uma mesa lisa e que é movimentada pelo deslocamento de um ímã colocado a alguma distância dela. $\mathrm{Na}$ ausência de qualquer impulso visível sobre o metal, a primeira reação de alguém desavisado seria de extrema surpresa, seguida pelo assombro em relação àquela seqüência de acontecimentos. Pasmo e hesitante, esta pessoa seria levada a se perguntar como aquilo poderia ter ocorrido e, para apaziguar sua perturbação, seria movida a encontrar alguma cadeia intermediária de eventos que permitisse unir aquela sequiência de acontecimentos tão insólita. Assim é que, quando imaginamos, a exemplo de Descartes, que alguns eflúvios invisíveis circulam em torno de um dos objetos e, deste modo, impulsionam o outro objeto a mover-se em direção ao primeiro, o intervalo é eliminado pela interposição de uma cadeia de acontecimentos que é conforme ao curso habitual das coisas. Com efeito, que um movimento ocorra depois de um impulso é uma seqüência de acontecimentos à qual estamos plenamente acostumados e, deste modo, a imaginação pode voltar a fluir suavemente de um objeto a outro, que agora já não parecem mais desconexos. Ainda que se julgue que tal explicação não seja completamente satisfatória, ela contribui para reduzir o nosso assombro diante da natureza ao lançar sobre os objetos algum tipo de conexão, algo que anteriormente lhes faltava por completo.

De fato, nem sempre a imaginação é inteiramente satisfeita pela explicação proposta: Smith reconhece que raramente somos capazes de descobrir de modo tão claro os princípios que conectam os assombros da natureza como o somos, ao contrário, em relação aos artefatos humanos. Quanto a estes últimos, depois de ter sido admitido nos bastidores de um teatro de ópera ninguém se espanta mais com os efeitos cênicos produzidos pelo maquinário de palco: o conhecimento do mecanismo permite que 
a imaginação não seja mais perturbada pela seqüência de efeitos de cena. ${ }^{20}$ Porém, em relação aos acontecimentos da natureza, poucas são as situações em que podemos considerar que fomos realmente admitidos nos bastidores. Esta impressão só ocorre em relação a alguns poucos "assombros da natureza", como os eclipses do sol e da lua, que despertavam terror e estupefação entre os antigos, mas que deixaram de nos assombrar desde que a cadeia de eventos que liga estes fenômenos ao curso habitual dos acontecimentos foi desvelada. (Astronomy II.8-9).

A esta altura é conveniente destacar o aspecto distintivo do argumento de Smith: nele, a busca do conhecimento é explicada em termos da necessidade de superar um sentimento subjetivo de desconforto. Neste sentido, o requisito básico para que uma hipótese dê conta do problema é que ela seja adequada a esta necessidade psicológica. Para tanto, ela deve ser capaz de explicar os fenômenos, bem como ser expressa em termos de algum princípio que seja familiar ou habitual. (Skinner, 1996, p. 31-32). Naturalmente, aquilo que é familiar para uma pessoa ou grupo pode não parecer assim para outro indivíduo: uma mesma seqüência de acontecimentos pode parecer corriqueira para alguém e ao mesmo tempo incoerente e desconexa para outros. Um artesão - um tintureiro ou um cervejeiro, por exemplo - acostumado a seguir determinada seqüência de operações em seu trabalho não sentirá qualquer assombro em relação à série peculiar de fenômenos que ocorrem ao longo do processo produtivo, ao passo que alguém alheio àquele universo não poderá deixar de se assombrar com a mesma seqüência espantosa e estranha de acontecimentos. ${ }^{21}$ Mas, se para o artesão não há qualquer necessidade de buscar um princípio que conecte aqueles fenômenos aos quais já está acostumado e que lhe parecem seguir uma ordem natural, o mesmo não ocorre aos outros homens e, em especial, aos filósofos. Estes últimos "freqüentemente procuram por uma cadeia de objetos invisiveis para unir dois eventos que ocorrem numa ordem que é familiar para todos" (Astronomy II.11), pois foram acostumados a se exercitar ao longo de toda sua vida no estudo dos princípios conectantes da natureza e sentem a existência de uma brecha ou hiato entre os objetos ali mesmo onde, para a maioria dos homens, só parece haver uma conjunção perfeita. O hábito de observar e comparar todos os tipos de conexão que se apresentam diante deles os torna mais aptos a notar a ausência daquela conexão estrita entre os objetos, da mesma maneira que o ouvido educado de um músico percebe o menor erro no ritmo ou na harmonia de uma execução musical que, para a maioria das pessoas, poderia passar despercebida. (Astronomy II.11).

20 Convém acrescentar que isso não nos impede de seguir sentindo admiração pelo espetáculo.

$21 \mathrm{Em}$ outro texto, Smith refere-se ao assombro provocado pelos espelhos nas pessoas que não estão habituadas a vê-los, assombro que pode chegar a um arrebatamento e até a um acesso. No entanto, ele nota, "depois de pouco tempo de uso e experiência, todos os espelhos cessam completamente de ser assombros. E mesmo o ignorante se torna tão familiarizado com eles que nem mesmo pensa que seus efeitos requerem alguma explicação." (Imitative Arts I.17). 
Deste modo, o filósofo está sujeito, em princípio, aos mesmos tipos de reação e aos mesmos sentimentos que o homem comum, pois ambos partilham da mesma natureza humana. Como Smith observaria mais tarde, na Riqueza das nações, as diferenças entre eles provêm sobretudo "do hábito, costume e educação" (WN I.ii.4): suas diferentes habilidades são antes o resultado da divisão do trabalho, e não sua causa. E o progresso da sociedade faz com que a filosofia se torne ela mesma um ramo da divisão do trabalho e o "ofício e ocupação principais ou exclusivos de uma classe específica de cidadãos." Esta classe é formada pelas pessoas que costumeiramente denominamos "filósofos on homens de especulação, cujo ofício não consiste em fazer alguma coisa, mas tudo observar; e que, por isso mesmo, são freqüentemente capazes de combinar os poderes dos objetos mais remotos e dessemelhantes." (WN I.i.9).

A existência da filosofia, entretanto, remonta a um período anterior a este estágio avançado da vida em sociedade e da divisão do trabalho. Ela surge a partir do momento em que a segurança e a ordem são estabelecidas pela lei e a subsistência deixa de ser precária. Antes disso, afirma Smith, os seres humanos teriam pouca curiosidade para descobrir os elos que ligam os acontecimentos aparentemente desconexos da natureza. A precariedade da vida e os perigos aos quais cada indivíduo estava sujeito tornariam as pessoas pouco propensas a se entregar ao estudo da filosofia que, aparentemente, não ofereceria a perspectiva imediata de qualquer resultado vantajoso além de "tornar o teatro da natureza um espetáculo mais conexo para sua imaginação" (Astronomy III.1). As pequenas inconsistências no curso dos acontecimentos que, para os olhos treinados de um filósofo, saltariam à vista, passavam despercebidas para aqueles "selvagens". Quanto aos fenômenos irregulares mais grandiosos - como trovões, eclipses, meteoros -, só podiam despertar o terror em suas mentes, tornando-os dispostos a crer neles como efeitos da vingança ou descontentamento de seres inteligentes, mas invisíveis, que seriam sua causa. De maneira análoga, diante das irregularidades da natureza que são belas e agradáveis, os mesmos selvagens atribuíam sua origem a seres inteligentes que se alegrariam com as expressões de gratidão e reverência que estes fenômenos naturalmente inspiram. Assim, a agitação do mar ou sua calmaria foram atribuídas a Netuno, as boas colheitas a Ceres, a abundância de uvas a Baco e assim por diante, de modo que, afirma Smith, podemos compreender a origem do politeísmo e das superstiçóes comuns que atribuem os acontecimentos irregulares da natureza a deuses, gênios, fadas etc.. Se a intervenção destes seres pode ser dispensada quando se trata de explicar fenômenos regulares ou o curso ordinário dos acontecimentos, ela se faz necessária sempre que o homem primitivo se deparava com ocorrências irregulares:

"O fogo queima e a água refresca, corpos pesados caem e substâncias leves se elevam pela necessidade de sua própria natureza; nem nunca se concebeu que a mão invisivel de Júpiter fosse empregada nestes assuntos. Mas o 
trovão e o raio, as tempestades e o bom tempo, estes acontecimentos mais irregulares foram imputados ao seu favor ou a sua ira. (...) E assim, nas primeiras evas do mundo, a superstição mais baixa e pusilânime ocupou o lugar da filosofia." (Astronomy III.1-2). ${ }^{22}$

Porém, quando aquelas duas circunstâncias mencionadas acima - o império da lei e condições seguras de subsistência - são estabelecidas numa sociedade qualquer, a filosofia passa a ser objeto de investigação. A ela se dedicam, sobretudo, aqueles indivíduos que, dispondo de riqueza abundante e tendo a imaginação livre das preocupações decorrentes dos assuntos ordinários da vida, podem ocupar-se com a observação dos acontecimentos que se desenrolam ao seu redor, começando pelos fenômenos celestes, mais grandiosos e belos, ${ }^{23}$ para descer, em seguida, à consideração dos objetos terrestres que, pela variedade de suas espécies e pela multiplicidade e aparente irregularidade das seqüências em que podem ser observados, são capazes, quando observados atentamente, de despertar o assombro e, com ele, a curiosidade por suas causas. (Ancient physics 1). Atentos a estes acontecimentos, os homens são necessariamente levados a conceber a existência de alguma cadeia que ligue todos os fenômenos aparentemente desconexos da natureza. Menos expostos aos perigos e, nesta medida, menos conscientes de suas debilidades do que de sua força e segurança, eles estarão menos propensos a ver ali a intervenção arbitrária daqueles seres invisíveis que o medo e a ignorância fizeram seus antepassados conceber. (Astronomy III.3). E assim como a superstição pretendera acalmar a imaginação atribuindo os fenômenos que provocavam assombro à ação dos deuses, a filosofia procurou dar conta deles remetendo-os a causas mais familiares à humanidade (WN V.i.f.24).

Smith retomaria a discussão sobre a conexão entre o desenvolvimento da filosofia e o da religião em uma passagem do ensaio sobre a História da física antiga. Para ele, assim como a ignorância gerou a superstição, a ciência ou filosofia teria dado origem ao teísmo entre aqueles povos que não conheciam a Revelação divina. Nos primórdios da humanidade, a incoerência dos fenômenos demoveu os homens de tentar descobrir no funcionamento da natureza qualquer traço de um sistema regular. Neste contexto, os deuses eram concebidos como seres que atuavam em situaçôes particulares e cuja existência era posterior à do mundo. Tão logo os filósofos imaginaram ter descoberto os elos da cadeia que liga os diferentes fenômenos e o universo passou a ser considerado um sistema coerente e regido por leis universais, a semelhança entre a natureza e

22 Este trecho é uma das três únicas passagens em que Smith emprega a expressão "mão invisível" que, mais tarde, acabaria estreitamente associada ao seu pensamento. Para uma discussão dos diferentes sentidos em que a expressão é empregada em cada uma das passagens, ver Ahmad (1990).

23 "Quanto mais intensa e chocante é a impressão feita por algum fenômeno na mente, maior a curiosidade que ele provoca para conhecer suas causas, conquanto o fenômeno, talvez, possa não ser intrinsecamente tão grande ou tão importante quanto algum outro menos notável. É assim que temos uma maior curiosidade para investigar a causa do trovão e relámpago e dos movimentos celestiais do que da gravidade, porque naturalmente eles provocam uma impressão maior sobre nós.” (LRBL ii.v.18-19). 
aquelas máquinas criadas pelos humanos fez com que os sábios passassem a acreditar na existência de alguma arte que tivesse sido empregada na criação do mundo, uma arte semelhante à humana, mas superior a ela na medida mesma da superioridade do universo em relação a qualquer artefato humano. Do mesmo modo, a unidade do sistema da natureza sugeriu aos filósofos antigos a unidade daquele princípio cuja arte deu origem ao mundo, "a idéia de um espirito universal, de um Deus de todos, que constituiu originalmente o todo e que governa o todo através de leis gerais, dirigidas à conservação e prosperidade do todo, sem levar em consideração a de qualquer individuo $\mathrm{em}$ particular." (Ancient physics 9).

Em resumo, a filosofia - e, com dela, certa concepção da providência divina - emerge deste relato como o resultado da tentativa de tornar o universo mais coerente, propugnando-se uma cadeia de eventos que permita ligar os fenômenos aparentemente desconexos da natureza. Esta tentativa tem por origem a necessidade de desembaraçar o curso da imaginação sempre que este é interrompido pelo sentimento de assombro:

"o primeiro princípio que impele os homens ao estudo da filosofia é, portanto, o assombro, e não a expectativa de obter alguma vantagem de suas descobertas (...); e eles seguem neste estudo a bem dele mesmo, como um prazer original ou um bem em si mesmo, sem considerar sua propensão de lhes granjear os meios para muitos outros prazeres." (Astronomy III.3).

Antes de extrair as conseqüências desta concepção de Smith para aquilo que nos interessa mais diretamente - isto é, antes de abordar a maneira como ele define a filosofia - é oportuno que nos detenhamos por um instante para comentar o aparente paralelismo entre o conceito smithiano de assombro (wonder) como princípio

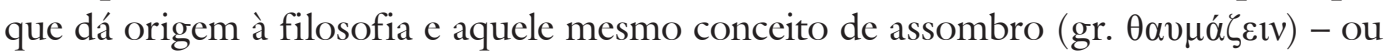
admiração, como é mais freqüentemente traduzido - que remonta aos gregos. ${ }^{24} \mathrm{Com}$ efeito, é sabido que, em certa passagem de um dos seus diálogos, Platão faz Sócrates afirmar que "a admiração é a verdadeira característica do filosofo. Não tem outra origem a filosofia.” (Teeteto, p. 155 d). Posteriormente, Aristóteles voltaria a este ponto:

"De fato, os homens começam a filosofar, agora como na origem, por causa da admiração, na medida em que, inicialmente, ficavam perplexos

24 Em relação ao conceito grego, Ferrater Mora esclarece que "em vez do termo 'admiração', podem-se usar os vocábulos 'assombro' e 'pasmo'." (Mora, 2001, p. 51). Na Modernidade, o conceito seria retomado por Descartes para designar uma das paixões básicas da alma. (Mora, 2001, p. 52). Curiosamente, os três conceitos analisados por Smith surgem numa passagem do parágrafo 53 d'As paixões da alma [Les passions de l'âme], ainda que numa seqüência e sentido diversos. Descartes afirma que o primeiro contato com um objeto que nos provoca surpresa ("nous surprend") faz com que o admiremos ("nous l'admirons") e nos assombremos com ele ("en sommes étonnés"). Noutro parágrafo do mesmo texto, o de número 70 , a admiração é definida como "uma súbita surpresa da alma, que a faz aplicar-se em considerar com atenção os objetos que the parecem raros e extraordinários." (Descartes, 1998, p. 76). 
diante das dificuldades mais simples; em seguida, progredindo pouco a pouco, chegaram a enfrentar problemas sempre maiores, por exemplo, os problemas velativos aos fenômenos da lua e aos do sol e dos astros, ou os problemas relativos à geração de todo o universo. Ora, quem experimenta uma sensação de dúvida e de admiração reconbece que não sabe; e é por isso que também aquele que ama o mito é, de certo modo, filósofo: o mito, com efeito, é constituido por um conjunto de coisas admiráveis. De modo que, se os homens filosofaram para libertar-se da ignorância, é evidente que buscavam o conhecimento unicamente em vista do saber e não por alguma utilidade prática. E o modo como as coisas se desenvolveram o demonstra: quando já se possuía praticamente tudo o de que se necessitava para a vida e também para o conforto e para o bem-estar, então se começou a buscar esta forma de conbecimento. É evidente portanto, que não a buscamos por nenhuma vantagem que the seja estranba; $e$, mais ainda, é evidente que, como chamamos livre o homem que é fim para si mesmo e não está submetido a outros, assim só esta ciência, dentre todas as outras, é chamada livre, pois só ela é fim para si mesma." (Met., A 2 982 b 12ss.).

Esta passagem sugere a existência de dois elementos em comum nos relatos de Smith e Aristóteles: ambos atribuem a origem da filosofia à mesma causa (o assombro) e ao mesmo período (aquele em que as preocupações mais imediatas com a sobrevivência já foram superadas). Entretanto, uma análise mais detida permite mostrar que há diferenças e nuanças nos textos que são reveladoras dos diferentes pontos de vista a partir dos quais estes autores enfrentam o problema. (Vivenza, 2001, p. 16ss.).

Em primeiro lugar, Aristóteles concebe a reação daquele que sente o assombro como a de alguém que "reconhece que não sabe". Neste sentido, o homem se tornaria filósofo exatamente para livrar-se de sua ignorância: uma reação cujo sentido é caracteristicamente intelectual. No texto de Smith, por sua vez, a ênfase recai sobre o sentimento de desconforto, incerteza e até mesmo medo que o assombro provoca. Se a reação a este sentimento consiste em buscar uma explicação para aquele objeto (ou aquela série de objetos) que tiraram a imaginação de seu repouso, esta explicação deve não apenas satisfazer a necessidade de conhecimento, mas, antes de tudo, restaurar a tranqüilidade da mente.

No que diz respeito ao segundo aspecto, o fato de Smith negar que algum motivo ou interesse "prático" oriente o surgimento da filosofia parece se aproximar do ponto de vista defendido pelos gregos. Esta impressão é ainda mais notável em razão do contraste que estabelece com relação às concepções de Bacon, tão influentes entre os autores modernos e, em particular, os iluministas escoceses. No entanto, também é 
possível mostrar que Aristóteles e Smith partem de motivações bastante diversas ao negarem a presença de qualquer interesse ligado a uma vantagem econômica entre os fatores que movem os homens a filosofar. Ao asseverar que a filosofia só teria começado depois de resolvidos os problemas materiais, Aristóteles está apenas buscando apoiar seu argumento central de que a filosofia ignora qualquer fim que lhe seja externo e, portanto, é uma ciência cujo fim está em si mesma. Smith, por sua vez, coloca a questão de um ângulo distinto: mesmo concordando que não são os motivos econômicos que impelem o homem a filosofar, não se trata, para ele, de mostrar que o filósofo ignora as questóes materiais, mas que o homem só pode começar a filosofar quando a sociedade alcançou certo grau de tranqüilidade em relação não apenas à sua subsistência, mas também sua segurança. Estes pré-requisitos comparecem no interior de um argumento sobre a conexão entre o progresso cultural e os estágios de desenvolvimento material da sociedade, argumento cujo sentido está muito mais voltado para apontar a importância das condições econômicas no desenvolvimento da filosofia do que para assegurar a condição do filósofo como homem livre de constrangimentos econômicos (a que Aristóteles faz referência ao final do trecho citado) ou para negar inteiramente algum valor ou sentido prático à ciência. Esta última leitura, afinal, estaria em contradição não apenas com o que constatamos anteriormente (cf. Cerqueira, 2006), a respeito da valorização da ciência entre os literati escoceses, como também com a maneira como a filosofia é descrita na Riqueza das naçôes. Nas palavras de Vivenza (2001, p. 18), trata-se de "um ótimo exemplo da maneira pela qual Smith assimilou os ensinamentos clássicos e os direcionou para seus próprios objetivos, preservando os tópicos, mas compreendendo-os e interpretando-os diferentemente", algo que, como veremos, irá se repetir em relação a outros problemas e conceitos.

\section{EVITANDO EQUÍVOCOS: O MÉTODO NEWTONIANO DE SMITH}

A maneira como Adam Smith define a filosofia está estreitamente associada ao que vimos até aqui e, em particular, ao modo como ele relaciona o sentimento de assombro ao impulso humano para filosofar. Para Smith, a "filosofia é a ciência dos princípios conectantes da natureza." (Astronomy II.12).

Confrontado com os numerosos fenômenos que a natureza oferece à observação e que parecem isolados e incoerentes em relação a tudo mais que conhecemos, o movimento da imaginação é interrompido, a passagem de uma idéia a outra só pode ser feita aos saltos. A filosofia surge, portanto, como um recurso para pacificar a imaginação:

"Ao representar os elos invisiveis que unem todos estes objetos incoerentes, a filosofia esforça-se para introduzir ordem neste caos de aparências dissonantes e discordantes, para apaziguar este tumulto da imaginação 


\section{e restaurar nela, quando examina as grandes revoluçôes do universo, aquele tom de tranqüilidade e compostura que é ao mesmo tempo mais aprazivel em si mesmo e mais adequado a sua natureza." (Astronomy II.12).}

Para um leitor de nossa época, a definição proposta por Smith pode soar insatisfatória: afirmando que "a filosofia é a ciência...", ela apresenta uma evidente dificuldade terminológica, na medida em que parece ignorar qualquer distinção entre estes dois tipos de conhecimento. A dificuldade torna-se ainda maior quando, algumas linhas à frente, o texto afirma que a filosofia "pode ser considerada como uma daquelas artes que falam à imaginação.” (Astronomy II.12). Filosofia, ciência e arte são termos empregados alternativamente por Smith, sem que se possa perceber exatamente se em que diferem. Seria, entretanto, impertinente, como nos alerta Wightman (1982, p. 12-13), exigir de um homem do século XVIII um uso preciso de conceitos que, até aquele período, eram empregados sem qualquer distinção. ${ }^{25}$

Neste sentido, é preciso tomar com cuidado aquelas interpretações da História da astronomia que pretendem ver neste ensaio algo que possa corresponder a uma "filosofia da ciência” smithiana. ${ }^{26} \mathrm{O}$ anacronismo envolvido neste tipo de interpretação fica patente se considerarmos que, do ponto de vista lingüístico ou conceitual, qualquer contemporâneo de Smith veria nesta expressão apenas uma tautologia ou uma fórmula desprovida de sentido. Com efeito, para que houvesse uma filosofia da ciência seria preciso, antes de tudo, poder distinguir o sentido daqueles dois conceitos. ${ }^{27}$ Além disso, esta forma de ler o ensaio revela-se ainda mais arriscada quando se tem em mente que o próprio conteúdo daquilo que, hoje em dia, chamamos de filosofia da ciência segue sendo objeto de muita controvérsia. Retrospectivamente, só seria possível considerar a História da astronomia como uma contribuição para as investigações que, mais tarde, viriam a compor esta disciplina se tomássemos o seu campo de estudos em um sentido bastante amplo, capaz de incluir os aspectos psicológicos (ou antropológicos) relacionados à criação do conhecimento científico - pois são estes aspectos que interessam a Smith naquele texto. Como ele próprio afirma, a filosofia se enquadra no campo temático de seu ensaio somente à medida que se dirige à imaginação, e é só por esta razão, afirma, que ele se dispõe a reconstituir sua trajetória desde seu início até a perfeição a que se supõe que tenha chegado, descrevendo suas grandes e freqüentes revoluções ao longo deste trajeto:

25 De acordo com o dicionário Oxford, os termos arte (art) e ciência (science) só foram demarcados na língua inglesa no final daquele século. Quanto aos termos filosofia e ciência, ainda que Hobbes já empregasse a expressão ciência natural no Leviatã, o termo filosofia natural permaneceu sendo o mais empregado nos séculos XVII e XVIII. (Wightman, 1982, p. 12-13).

26 Cf. Thomson (1984), entre outros.

27 Igualmente, não há sentido em atribuir algum significado especial ao fato de Smith qualificar Newton de filósofo, ao invés de cientista, como faz Thomson (1984, p. 327). Tanto mais que o termo cientista só surgiria no século XIX. (Wightman, 1982, p. 13). 
"Vamos, portanto, examinar todos os diferentes sistemas da natureza (...) que têm sido sucessivamente adotados pelos doutos e engenhosos; e, sem julgar seu despropósito ou sua probabilidade, seu acordo ou sua inconsistência com a verdade ou a realidade, vamos considerá-los apenas daquele ponto de vista particular que é próprio do nosso tema e nos contentarmos em investigar até onde cada um deles era qualificado a acalmar a imaginação e a tornar o teatro da natureza um espetáculo mais coerente e, portanto, mais grandioso do que ele, de outro modo, teria parecido ser." (Astronomy II.12).

Neste exame, os sistemas astronômicos são apresentados numa ordem determinada. De acordo com Smith, no momento em que foram concebidos, cada um deles era capaz de acalmar a imaginação. Com o tempo, novas observações ou observações mais acuradas que as anteriores deram origem a novos problemas que exigiram, por sua vez, que os sistemas fossem adaptados ou alterados para dar conta destas questóes. Assim, a descoberta de novos corpos celestes ou aferição mais precisa de suas órbitas exigiu, por exemplo, que se introduzissem epiciclos naqueles sistemas já existentes para que continuassem capazes de explicar a trajetória dos astros. (Astronomy IV.16ss.). Entretanto, a cada modificação o sistema vai se tornando mais complexo e intrincado e, nesta medida, termina perdendo a capacidade de satisfazer a imaginação. É necessário então que se conceba um sistema alternativo, capaz de dar conta daqueles problemas, mas que, simultaneamente, seja mais simples que o seu antecessor e, neste sentido, mais apto a pacificar o espírito.

Esta trajetória culmina na exposição do sistema newtoniano. Ao colocar a gravidade como o princípio que conecta os movimentos dos diferentes planetas, Newton teria alcançado "o maior e o mais admirável melhoramento jamais feito em filosofia." (Astronomy IV.67). Ao explicar com base nela a trajetória aparentemente tão inconstante dos cometas, ele introduziu uma coerência tão completa no movimento dos astros que aquele princípio foi recomendado em grau à imaginação da humanidade. (Astronomy IV.74). Para tanto, a gravidade contava ainda com a vantagem de ser um princípio ao qual estamos acostumados, pois, segundo Smith, depois da inércia, ela é a qualidade da matéria que nos é mais familiar. ${ }^{28}$

28 Wightman (1982, p. 21-22) faz restrições a esta opinião de Smith com base nas críticas que filósofos como Leibniz fizeram ao princípio da gravitação, qualificando-o de um "milagre" ou "blasfêmia" por pressupor uma ação instantânea entre objetos situados a distâncias imensas. No entanto, a opinião de Smith era compartilhada, em sua própria época, por Colin Maclaurin, entre outros, o mais importante divulgador da física newtoniana entre os escoceses. Comentando os Princípios de Newton, Maclaurin afirma que "ele descreve o sistema do mundo e demonstra os poderes que governam os movimentos celestes e produzem suas influências reciprocas. (...) Nem são estes princípios novos e abstrusos, como aqueles que nunca tiveram existência exceto na imaginação dos filósofos, mas os mesmos que são mais familiares à humanidade e de uso comum, ampliados e definidos de maneira mais precisa." (Maclaurin, 1997, p. 792-793). 
Vencendo as restrições que lhe fizeram inicialmente os cartesianos, afirma Smith, o sistema newtoniano passou a prevalecer contra toda oposição e de modo mais universal que qualquer outro sistema filosófico. Seus princípios teriam tal solidez, conectariam de maneira tão perfeita os fenômenos observados antes ou depois de sua criação, que nem mesmo um cético poderia evitar o sentimento de que seria inútil buscar algum outro sistema para substituí-lo.

Mas, ao afirmar isto, já se aproximando das linhas finais do ensaio, Smith parece se dar conta de que, em razão do seu entusiasmo pelo sistema de Newton, ele se afastara sem se aperceber do objetivo que traçara no início de sua exposição. Nota, então, que

“... até mesmo nós, que estivemos empenhados em representar os sistemas filosóficos como meras invenções da imaginação (...), fomos imperceptivelmente seduzidos a fazer uso da linguagem que exprime os princípios conectantes deste sistema [newtoniano] como se fossem as cadeias reais de que a Natureza faz uso para unir suas várias operações. Não podemos nos assombrar então de que ele tenha ganhado a aprovação geral e completa da humanidade e de que seja considerado agora, não como uma tentativa de conectar na imaginação os fenômenos dos céus, mas como a maior descoberta jamais feita pelo homem, a descoberta de uma imensa cadeia das mais importantes e sublimes verdades, todas estreitamente conectadas por um fato capital de cuja realidade temos a experiência diária." (Astronomy IV.76).

Trechos como este despertaram, em alguns leitores de Smith, a impressão de que ele pudesse ser considerado um representante de alguma forma de "anti-realismo" ou "convencionalismo". ${ }^{29}$ Convém observar, entretanto, que tal leitura só se sustenta se deixarmos de lado o objetivo explicitamente declarado por Smith em relação ao tipo de investigação - psicológica - que ele perseguiria ao longo do ensaio. Implica, além disso, desconsiderar o papel que a observação cumpre na descrição que Smith faz da evolução dos sistemas da natureza ${ }^{30}$ e sua admissão explícita da existência de um mundo exterior. ${ }^{31}$ Para retomar as palavras de Berry (1997, p. 60), ler Smith como um adepto do convencionalismo é sobrecarregá-lo com sutilezas que são mais próprias da filosofia do século XX: aos olhos de um contemporâneo do Esclarecimento, uma

29 A principal interpretação nesta linha é aquela proposta por Lindgren (1969).

30 Cf. a interpretação que Lindgren (1969, p. 900) faz do papel da observação em Smith, que não nos parece defensável.

31 Contra os argumentos extraídos daquela espécie de metafísica "que confunde tudo e não explica nada", Smith argumenta "que qualquer que seja o sistema que possa ser adotado em relação à dureza ou suavidade da substância resistente, sua fluidez ou solidez, sua compressibilidade ou incompressibilidade, a certeza de nosso sentido e sensação inconfundiveis de sua externalidade, de sua inteira independência em relação ao órgão que a percebe, ou por meio do qual a percebemos, não pode ser minimamente afetada por este sistema." (External senses 18). 
concepção anti-realista só poderia ser considerada (se efetivamente pudesse ser concebida) como solapadora daquela visão de ciência proposta por Bacon e amplamente compartilhada pelos iluministas escoceses.

Convém acrescentar que, ao contrário da maioria dos filósofos da Modernidade, Smith raramente expressou sua opinião a respeito de questões epistemológicas. Neste sentido, a originalidade da História da astronomia repousa, especialmente, no ponto de vista adotado por seu autor, segundo o qual o valor dos diferentes sistemas filosóficos é medido apenas em função de sua capacidade de tranqüilizar a imaginação e todas as proposições científicas são mantidas como hipotéticas e, como tais, passíveis de mudança. (Skinner, 1996, p. 41). Convém notar, a propósito, que o próprio Newton considerou o seu sistema como uma espécie de "ponto de repouso" provisório no progresso da ciência experimental. (Cassirer, 1994, p. 83). Porém, esta atitude cautelosa, ao mesmo tempo que preserva a diferença entre a teoria e seu objeto, está longe de negar a realidade do mundo.

Com efeito, a idéia de que Adam Smith e Isaac Newton tenham algo em comum - algo que, segundo Redman (199, p. 207), poderia soar como remoto ou vago para a maioria dos economistas ou dos historiadores da ciência - tem se expressado com certa freqüência na literatura. Como a mesma Redman reconheceu, os leitores mais atentos de Smith não deixaram de notar suas referências ao "método newtoniano", nem foram poucos os estudos recentes que pretenderam ver naquele método o procedimento efetivamente adotado em suas obras. Blaug (1993, p. 97), por exemplo, é um dos que consideram o papel desempenhado pela simpatia, na Teoria dos sentimentos morais, e pelo auto-interesse, na Riqueza das nações, como demonstrações claras de que estes livros consistem em "tentativas deliberadas de Smith para aplicar o método newtoniano primeiro à ética e depois à economia." Declarações como esta, repetidas em vários outros textos, sugeririam à primeira vista uma espécie de consenso entre os especialistas. Entretanto, uma análise mais detida do que afirmam estes intérpretes pode revelar o que há de inócuo ou até de perigosamente enganador nestas leituras do problema: tudo depende de saber - e nisso reside a dificuldade - o que é que se pretende propriamente afirmar quando o adjetivo newtoniano é empregado para caracterizar o método adotado por Smith. Ou, dito de maneira mais concisa, que tipo de newtoniano era Smith? (Redman, 1997, p. 208ss.; Montes, 2003). Para responder a esta questão é conveniente desdobrá-la em duas outras: a primeira diz respeito à própria natureza da visão de Newton sobre o conhecimento; a segunda concerne à compreensão que Smith tinha do método newtoniano.

No que toca ao primeiro aspecto, foge completamente ao objetivo deste ensaio empreender uma revisão do pensamento científico-filosófico de Newton, mas é preciso assinalar de saída que, nos últimos anos, a interpretação de sua obra vem sendo objeto 
de uma extensa revisão, motivada especialmente pela pesquisa de seus escritos alquímicos e teológicos. Além disso, é importante ressaltar que, ao contrário da leitura positivista do seu método - leitura amplamente compartilhada pelos economistas contemporâneos e cuja raiz remonta à interpretação que alguns filósofos franceses do século XVIII fizeram de sua obra -, Newton não advogou uma visão mecanicista do mundo, nem endossou o método axiomático-dedutivo característico da economia walrasiana, vertente teórica que dominou o pensamento econômico na segunda metade do século XX. Contra Descartes, Huygens e Leibniz, ele se opôs à tentativa de reduzir os fenômenos naturais a um simples mecanismo e, apesar de ter procurado estabelecer os princípios matemáticos que regem o seu curso, rejeitou de maneira determinada a tentativa cartesiana de reduzir a física à geometria. Ao contrário, Newton advogou que a física deveria se apoiar na experimentação e no raciocínio indutivo, opondo ao ideal da dedução a análise daquilo que nos é dado diretamente pela observação. (Cassirer, 1994, p. 82-89). Em suas próprias palavras, seu método é uma combinação de análise e de síntese:

"... também na filosofia natural a investigação das coisas difíceis pelo método da análise deve sempre preceder o método da composição. Esta análise consiste em fazer experimentos e observações e tirar deles conclusões gerais por meio da indução (...) E a sintese consiste em admitir as causas descobertas e os princípios estabelecidos e, através deles, explicar os fenômenos que deles procedem e provar as explicaçôes." (Newton, 2004, p. 380-381).

Convém acrescentar que os literati escoceses estavam bem a par desta concepção. Ao expor o método proposto por Newton, Maclaurin explica que, para ele,

"os métodos da análise e da sintese deveriam ser ambos empregados em uma ordem apropriada; que nós deveríamos começar com os fenômenos ou efeitos e a partir deles investigar os poderes ou causas que operam na natureza; que das causas particulares nós deveríamos passar para as mais gerais, até o final do argumento na mais geral: este é o método da análise. Uma vez estando de posse destas causas, nós deveríamos então proceder em uma ordem inversa; e delas, como princípios estabelecidos, explicar todos os fenômenos que são suas conseqüências e provar nossas explicações: e esta é a síntese." (Maclaurin, 1997, p. 785).

Sabemos, entretanto, que o próprio sucesso da representação matemática do sistema da natureza contida nos Principia estimulou uma interpretação moderna do método newtoniano na qual a prioridade da análise foi sobrepujada pela ênfase no movimento de síntese. Ocorreu, neste sentido, uma curiosa inversão: a impressão viva e 
absorvente provocada pelo resultado alcançado por Newton (seu sistema matemático) deslocou e obscureceu a justa compreensão do seu método, especialmente quanto à apreensão de seus dois momentos (o analítico e o sintético). De modo análogo, a atração universal que, para Newton, era prova da insuficiência de toda explicação puramente mecânica do mundo, tornou-se nestas variantes do newtonianismo uma propriedade da matéria em que se apóia uma visão mecanicista do universo. (Montes, 2003, p. 728-30).

No que diz respeito ao segundo aspecto do problema formulado acima - a saber: que tipo de newtoniano era Smith -, a dificuldade reside, inicialmente, em superar os preconceitos amplamente difundidos entre os economistas, que vincularam a concepção metodológica de Smith àquela orientação que prevalece atualmente na teoria econômica. Trata-se, em outras palavras, de abandonar as leituras que fazem de Smith um precursor da teoria walrasiana do equilíbrio geral, de recusar as interpretaçóes construídas a partir daquele pressuposto formulado por Samuelson segundo o qual "dentro de todo economista clássico existe um economista moderno tentando ser reconbecido." (Samuelson, 1977, p. 42). Aos olhos destes intérpretes, a teoria smithiana aparece como uma tentativa de representar a sociedade ao modo da mecânica newtoniana: a ordem econômica seria entendida como o resultado da ação de indivíduos independentes (os átomos sociais) que perseguiriam exclusivamente seu auto-interesse, sendo o equilíbrio dos mercados alcançado por meio do jogo da oferta e demanda que faria com que os preços gravitassem em torno de seu ponto de equilíbrio. O que se quer frisar aqui é que esta concepção supõe, a um só tempo, uma interpretação parcial e enviesada do método newtoniano (que se restringe ao seu momento dedutivo e enfatiza seu aspecto matemático) e uma compreensão equivocada do esforço teórico de Smith. ${ }^{32}$

Se é fato que, ao construir sua teoria econômica, Walras procurou transpor os esquemas da mecânica clássica para seu modelo de equilíbrio geral, a tentativa de representar a visão de Smith como mecanicista ou atomista não resiste a uma análise mais detida de sua obra. ${ }^{33}$ Em parte, este tipo de interpretação poderia decorrer da presença de termos como "gravitação" dos preços ou "centros de repouso", que Smith faz uso

32 Entre os adeptos mais ilustres da interpretação que se está criticando, podem ser mencionados Arrow e Hahn (1977, p. 14), que afirmam ser possível sustentar que Smith foi "o criador da teoria do equilibrio geral" (ainda que qualifiquem sua opinião afirmando não haver em sua obra nada que se pareça com um argumento rigoroso ou uma apresentação cuidadosa da proposição da eficiência) e o próprio Samuelson (1977), que aponta na análise de Smith uma "antecipação válida e valiosa" dos modelos de equilíbrio geral.

33 A inspiração direta de Walras é o manual de mecânica pura escrito por Louis Poinsot em 1803, os Elementos de estática [Éléments de statique]. A este respeito, ver Paula (2002), para quem "nada há de central em Walras derivado de Adam Smith." 
na Riqueza das naçôes. ${ }^{34}$ De outro lado, poderia também reivindicar em seu apoio aquelas passagens nas quais Smith compara os sistemas filosóficos, ${ }^{35}$ o universo ${ }^{36}$ e a própria sociedade ${ }^{37}$ a máquinas. Entretanto, quando analisadas em seu devido contexto, estas “evidências” não permitem suportar aquela conclusão. Com efeito, o uso de analogias mecânicas era algo bastante disseminado no século XVIII e sua presença não basta para fazer de Smith um representante do mecanicismo. Se a analogia com as máquinas é empregada por Smith para chamar atenção para o modo como o mundo ou a sociedade podem ser explicados - ou seja, encarando cada evento como o efeito de uma causa a ser identificada -, o andamento geral de sua abordagem poderia ser melhor caracterizado como "evolucionista", 38 pois a história das sociedades é vista por Smith como um processo complexo de adaptação de suas instituições, que evoluiriam em resposta às ações não-intencionais dos homens ao longo dos diferentes estágios de desenvolvimento até atingir o estágio de sociedade comercial. (Redman, 1997, p. 219-24; Monte, 2003, p. 739-41).

Além disso, a abordagem proposta por Smith difere daquela seguida pela teoria econômica contemporânea por evitar o emprego da matemática - o que, neste caso, representa também um distanciamento em relação a Newton. A despeito de a matemática ser uma das disciplinas favoritas de Smith durante sua juventude ${ }^{39}$ e do fato dele nunca ter se declarado contrário, em princípio, a ela, o emprego da matemática na Riqueza das nações não vai além de simples cálculos de médias. Não há ali nada que seja comparável ao emprego que Newton faz da álgebra, da geometria ou de seu cálculo de fluxões. Pode-se discutir as razões que motivaram este alheamento de Smith em relação à matematização, mas entre os aspectos que podem ter influenciado sua

34 No capítulo 7 do livro I, ele afirma que "o preço natural é, portanto, por assim dizer, o preço central para o qual os preços de todas as mercadorias estão continuamente gravitando. (...) ... quaisquer que sejam os obstáculos que os impeçam de se fixar neste centro de repouso e permanência, eles estão constantemente tendendo para ele." (WN I.vii.15).

35 "Sistemas assemelham-se em muitos aspectos às máquinas. Uma máquina é um pequeno sistema, criada para executar, bem como para conectar na realidade aqueles diferentes movimentos e efeitos que o artesão necessita. Um sistema é uma máquina imaginária inventada para conectar na imaginação aqueles diferentes movimentos e efeitos que já são executados na realidade." (Astronomy iv.19).

36 "... as várias aparências que a grande máquina do universo está perpetuamente exibindo, com as rodas e molas secretas que as produzem .... ." (TMS I.i.4.2).

37 "A sociedade humana, quando a contemplamos sob certo ponto de vista filosófico e abstrato, aparece como uma grande, uma imensa máquina, cujos movimentos harmônicos e regulares produzem mil efeitos agradáveis." (TMS VII.iii.1.2).

38 No sentido do evolucionismo econômico, corrente teórica cuja origem remonta à obra de Thorstein Veblen (1857-1929), e que prioriza a análise dos hábitos e das instituições que caracterizam cada estágio da vida em sociedade, concebendo-os em processo de permanente mudança qualitativa. Contrapóese, neste sentido, ao atomismo e ao mecanicismo da abordagem dominante, que enfatiza a análise de estados de equilíbrio alcançados a partir das escolhas racionais de cada agente. Sobre o evolucionismo econômico, ver Cerqueira (2002) que, entretanto, incorre no equívoco de atribuir a Smith uma visão mecanicista da economia (cf. p. 62-63).

39 Dugald Stewart (1982, p. 244-45) registra o depoimento de um dos colegas de Smith no período de estudante em Glasgow, que atesta seu interesse por matemática e filosofia natural. O mesmo autor recorda ainda uma referência de seu pai a um problema de geometria de considerável dificuldade com o qual Smith estivera envolvido no período em que se conheceram. 
opção incluem-se, provavelmente, a atitude cautelosa que os escoceses nutriam em relação ao emprego da matemática ${ }^{40}$ e o temor de que, levado ao extremo, o "espírito sistematizante" (que Smith associava à matematização) terminasse por produzir sistemas engenhosos e elegantes, mas excessivamente simplificadores e afastados dos fatos, sistemas falaciosos como os de Descartes. (Redman, 1997, p. 217-8). ${ }^{41}$

Buscando concluir, pode-se afirmar que a defesa que Smith faz do método newtoniano permitiu que, a despeito da ampla evidência em contrário proporcionada por sua obra, muitos leitores concluíssem que ele era um adepto do método axiomáticodedutivo e mecanicista que se atribuiu a Newton e que veio a dominar o pensamento econômico contemporâneo. Para tanto, parecem ter contribuído tanto uma compreensão "positivista" do método proposto por Newton quanto uma leitura de Smith que se ateve apenas a suas observações sobre o método de exposição do argumento - método que ele julga ser o mesmo empregado por Descartes e Newton - e desconsidera o papel que a observação e a indução desempenham em relação ao seu método de investigação. ${ }^{42}$ No que diz respeito ao primeiro aspecto - expositivo ou retórico -, a ênfase recairia no emprego de alguns poucos princípios familiares com base nos quais os fenômenos devem poder ser deduzidos e conectados. Porém, mesmo admitindo que Smith tenha escrito muito pouco sobre questões de método, seria um equívoco restringir sua concepção metodológica a este aspecto. Com efeito, ao discutir como as regras gerais da moralidade são formadas, ele afirma que:

"As máximas gerais da moralidade são formadas, assim como todas as
outras máximas gerais, a partir da experiência e indução. Observamos
em uma grande variedade de casos particulares o que agrada ou desa-
grada às nossas faculdades morais, o que elas aprovam ou desaprovam

40 Longe de representar uma rejeição da matemática, esta atitude consistia numa recusa em associar o valor de qualquer disciplina ao grau de formalização matemática nela empregado, bem como numa preferência pela geometria em relação à álgebra. Este último aspecto decorria do fato de que na geometria os passos de qualquer argumento são expostos e analisados cuidadosamente, contribuindo para o desenvolvimento do intelecto, ao passo que na álgebra o emprego de símbolos como que substituiria o processo de argumentação, introduzindo uma espécie de obscuridade. Convém acrescentar que isso não impediu que um dos moralistas escoceses mais proeminentes, Hutcheson, se aventurasse em tentativas de formalização matemática de sua filosofia moral, esforço que não foi seguido nem por Hume, nem por Smith, e que o próprio Hutcheson, mais tarde, descartou como algo inútil. (Redman, 1997, p. 114-118).

41 Sobre este último ponto, ver o comentário de Smith sobre o "homem de sistema". (TMS VI.ii.2.17).

42 Uma espécie de leitura que remonta ao século XIX. Escrevendo por volta de 1888, John K. Ingram, um historiador do pensamento econômico adepto de Comte afirmava que "tem havido muita discussão sobre a questão: 'qual é o método científico seguido por Smith em sua grande obra'. Alguns consideram ter sido simplesmente dedutivo, uma visão que Buckle, talvez, tenha levado ao maior extremo. Ele afirma que na Escócia o método indutivo era desconbecido... (...). Certamente não é verdade que o espirito indutivo não tenba exercido qualquer influência sobre os filósofos escoceses (...). Quanto ao próprio Smith, o que pode ser dito com justiça a seu respeito é que a propensão dedutiva não era certamente a característica predominante de seu espirito... ." (Ingram, 2005). Sobre o sentido desta controvérsia no século XIX, veja-se também o artigo de Cliffe Leslie (1984). 
e, por indução desta experiência, estabelecemos aquelas regras gerais." (TMS VII.iii.2.6, grifo nosso).

Pode-se dizer, portanto, que estas regras são derivadas da razão, na medida em que a indução é uma operação da razão. Todavia, complementa Smith, isso não nos autoriza a pensar que as primeiras percepções do que é certo ou errado derivem da razão, pois

"Estas primeiras percepções, bem como todas as outras experiências sobre as quais quaisquer regras gerais se fundam, não podem ser objeto da razão, mas do sentido e sentimento imediatos. Formamos as regras gerais de moralidade descobrindo numa grande variedade de casos que um teor de conduta agrada constantemente num certo procedimento e que outro, com igual constância, desagrada a mente.” (TMS VII.iii.2.7; grifo nosso).

Deste modo, não resta dúvida de que Smith recomenda que a investigação seja conduzida empiricamente, com base na observação e na experimentação (esta última igualada à introspecção). ${ }^{43}$ Somente depois que os princípios universais da natureza humana forem obtidos indutivamente é que pode ter início a exposição do sistema com base nestes princípios, conectando-os dedutivamente aos diferentes fenômenos. Neste sentido, Newton e Bacon são, para ele, os exemplos a serem seguidos e foi esta concepção de método que ele materializou em sua filosofia moral e economia política.

\section{REFEREANCLAS BIBLIOGRÁFICAS}

Ahmad, S. Adam Smith's four invisible hands. History of Political Economy, v. 22, n. 1, p. 137-144, 1990.

Aristóteles. Metafísica. Edição bilíngüe com tradução de Marcelo Perine. São Paulo: Loyola, 2002.

Arrow, Kenneth; Hahn, Frank [1971]. Análisis general competitivo. México: FCE, 1977.

Berry, Christopher. Social theory of the Scottish enlightenment. Edinburgh: Edinburgh University Press, 1997.

Blaug, Mark. [1980]. Metodologia da economia. Tradução de Afonso Lima. São Paulo: EDUSP, 1993.

43 A este propósito, Redman (1997, p. 209-10; 214; 171-3) observa que, para Smith, a indução de nossas experiências está referida à operação de generalizar um princípio por meio da consideração de um grande número e variedade de casos particulares, concepção mais próxima daquela exposta por Bacon e por alguns seguidores de Newton. Este último, ao contrário, ainda que contemple em sua obra esta mesma concepção, sempre preferiu se guiar pelos resultados de algum experimento crucial, simples e bem concebido. 
Brown, Vivienne. Adam Smith's discourse: canonicity, commerce and conscience. London: Routledge, 1994.

Bryce, J. C. (ed.) [1963]. Introduction. In: Smith, Adam, Lectures on rhetoric and belles lettres. Indianapolis: Liberty Fund, 1985.

Cassirer, Ernst. [1932]. A filosofia do iluminismo. Tradução de Álvaro Cabral. Campinas: Ed. da Unicamp, 1994.

Cerqueira, Hugo. A economia evolucionista: um capítulo sistêmico do pensamento econômico? Análise Econômica, v. 20, p. 55-79, 2002.

. Para ler Adam Smith: novas abordagens. Sintese - Revista de Filosofia, v. 32, n. 2, 2005.

. Adam Smith e seu contexto: o Iluminismo escocês. In: X Encontro Nacional de Economia Política, 2005, Campinas. Anais..., 2006.

Descartes, René. As paixões da alma. Tradução de Rosemary C. Abílio. São Paulo: Martins Fontes, 1998.

Howell, Wilbur S. Adam Smith's lectures on rhetoric: an historical assessment. In: Skinner, Andrew; Wilson, Thomas, Essays on Adam Smith. Oxford: Clarendon Press, 1975, p. 11-43.

Hume, David. [1739-40]. A treatise of human nature. Ed. L. A. Selby-Bigge, revista por P. Nidditch. Oxford: Clarendon Press, 1978.

Ingram, John Kells. [1888]. A history of political economy. (McMaster University Archive for the History of Economic Thought), 2005. [Disponível em http://socserv. mcmaster.ca/econ/ugcm/3ll3/ingram/index.html; acesso em 28/02/2005].

Leslie, L. T. E. Cliffe. [1870]. The political economy of Adam Smith. In: Wood, John C. (ed.), Adam Smith: critical assessments. Vol. 5, London e New York: Routledge, 1994.

Lindgren, J. R. Adam Smith's theory of inquiry. Journal of Political Economy, v. 77, n. 6, p. 897-915, 1969.

Maclaurin, Colin. A general view of Sir Isaac Newton's method, and of his account of the system of the world. In: Broadie, Alexander (ed.), The Scottish enlightenment: an anthology. Edinburgh: Canongate, 1997 [trecho extraído de Account of Sir Isaac Newton philosophical discoveries, London, 1748].

Montes, Leonidas. Smith and Newton: some methodological issues concerning general economic equilibrium theory. Cambridge Journal of Economics, v. 27, p. 723-747, 2003.

Mora, José Ferrater. Dicionário de filosofia. Tradução portuguesa. São Paulo: Loyola, 2001.

Newton, Isaac. [1718].Opticks: or, a treatise of the reflections, refractions, inflexions and colours of light. London, W.; Innnis, J. [Reprodução em fac-símile da $2^{\text {a }}$ edição com acréscimos disponível em http://dibinst.mit.edu/BURNDY/BURNDY/Collections/Babson/OnlineNewton/Opticks.htm; acesso em dezembro de $2004]$. 
Paula, João A. Walras no 'Journal des Economistes': 1860-65. Revista Brasileira de Economia, v. 56, n. 1, p. 121-146, 2002.

Platão. Teeteto - Crátilo. $3^{\text {a }}$ ed. revista. Tradução de Carlos A. Nunes. Belém: EDUFPA, 2001.

Rae, John. [1895]. The life of Adam Smith. New York: Augustus M. Kelley, 1965.

Redman, Deborah. The rise of political economy as a science. Cambridge, MA: MIT Press, 1997.

Ross, Ian. The life of Adam Smith. Oxford: Clarendon Press, 1995.

Samuelson, Paul. A modern theorist's vindication of Adam Smith. American Economic Review, v. 67, p. 42-9, 1977.

Schumpeter, Joseph A. [1954]. History of economic analysis. London: Routledge, 1994.

Skinner, Andrew. Early writings: science and the role of imagination. In: . A system of social science. Oxford: Clarendon Press, 1996, p. 25-47.

Smith, Adam. [1776]. An inquiry into the nature and causes of the wealth of nations. Eds. R. H. Campbell; A. S. Skinner; W. B. Todd.). Indianapolis: Liberty Fund, 1981.

. [1759]. The theory of moral sentiments. Eds. D. D. Raphael; A. L. Macfie. Indianapolis: Liberty Fund, 1982.

. [1795]. Essays on philosophical subjects. Ed. W. P. D. Wightman. Indianapolis: Liberty Fund, 1982.

. Lectures on rhetoric and belles lettres. Ed. J. C. Bryce. Indianapolis: Liberty Fund, 1985 [1963].

. Correspondence of Adam Smith. Eds. E. C. Mossner e I. S. Ross. Indianapolis: Liberty Fund, 1987.

Stewart, Dugald. Account of the life and writings of Adam Smith, L. L. D. In: Smith, Adam, Essays on philosophical subjects. Ed. W. P. D. Wightman. Indianapolis: Liberty Fund, 1982, p. 269-351.

Thomson, H. F. [1965]. Adam Smith's philosophy of science. In: Wood, John C. (ed.), Adam Smith: critical assessments. Vol. 1, London e New York: Routledge, 1984.

Vivenza, Gloria. [1984]. Adam Smith and the classics: the classical heritage in Adam Smith's thought. Tradução inglesa. Oxford: Oxford University Press, 2001.

Wightman, W. [1980]. Introduction. In: Smith, Adam, Essays on philosophical subjects. Indianapolis: Liberty Fund, 1982, p. 5-27. 